\title{
Venture Capital in Europe: investors and targets
}

\begin{abstract}
Venture capital is a key driver for the growth and development of business and its importance in Europe has been increasing in the last decades. This study provides additional insight on venture capital by evaluating the characteristics of the venture capitalists (VCs) that operate in Europe and by giving an overview of the investment strategies and portfolios, as well as of the characteristics of the funded businesses and the level of survivorship of targets. The analyses suggest that VCs tend to invest more in high tech industries and confirm the cyclicality of VC, as the number of investments and the sum invested decreased during the crisis.
\end{abstract}

Keywords: venture capital; target; investment portfolio; investment strategies; Europe; survivorship; crisis. JEL: G24

\section{Introduction}

Venture capital is a form of intervention in new firms, or also in companies that need to introduce a substantial innovation, and it is performed by specialised investors - venture capitalists, VCs - that are able to overcome asymmetries of information and the uncertainty that characterise this type of investments. Prior to capital injection, VCs perform screening activities to select only the best business ideas, and during the investment phase they perform monitoring activities, to track the performance of the target firm. During the monitoring, the VCs generally also provide value added services, transferring financial and managerial skills to the target.

The literature suggests that venture capital is a key driver for the growth and development of new businesses and for the whole economy (Gompers, 1995; Metrick and Yasuda, 2011), especially during downturns, when VC operates as alternative source of funds, because bank loans offer decreases or faces more restrictive conditions.

The benefits for the VC backed firms are various. In general, target companies show a higher growth rate, as well as higher revenue, employment rate, margin and income level (Croce et al, 2013). Moreover, VC backed businesses register a higher rate of survivorship and a better return at the time of exit (Gompers, 1996; Jain and Kini, 2000). In fact, although usually firms are underpriced at the time of the IPO, this underpricing appears to be lower for VC backed firms (Barry et al, 1990), although evidence is contrasting (Brav and Gompers, 1997; Brau et al, 2003).

This study aims at analysing the characteristics of VCs that operate in Europe, examine their investment strategies and evaluate the level of survivorship of the target firms. The research contributes to the existing literature by providing an updated analysis of VC investment portfolios, but also by investigating the crisis period which has not been studied yet in detail by the specific literature on venture capital.

The rest of the paper is structured as follows: section 2 reviews theories and previous evidence; section 3 presents the sample and the methodology; section 4 analyses the investment portfolios; section 5 presents the data on exit strategies and evaluates the survivorship rate; the final section concludes.

\section{The features of venture capital in Europe}

Venture capitalists invest in target companies through equity or quasi-equity instruments in a medium-long term perspective. This type of intervention is generally included in the broad area of private equity, which refers to the funding of private firms. VC intervention can be classified according to the stage of the target firm at the time of the investment (EVCA, 2013). The first stage, named seed financing, relates to informal entrepreneurial ideas, in which the main asset is represented by the innovative business idea; venture capital in this context aims at supporting the research and development of the product or service. Firms in the second phase (early stage) have a 
formal entrepreneurial idea, but they have not entered the market yet. VCs might provide capital to finance the development of the product and the marketing phase. Finally, firms receiving investments for expansion and later stage are already active and operating, but need to expand their production or introduce an important innovation. This distinction is not exhaustive and boundaries between stages are blurred; nevertheless, it provides a first guideline to understand the type of contribution of venture capital to new or existing firms.

VC is particularly suitable for new firms (Kaplan and Stromberg, 2001) because it is able to reduce asymmetries of information and provide support to new businesses which typically face more capital constraints (Dal-Pont Legrand and Pommet, 2010). New firms might not have access to funds through the traditional channels, such as bank lending or raising funds via the market. In fact, banks might consider new firms as particularly risky and to compensate for this, they might increase the interest rate. This however might have the perverse effect to scream only the worse borrowers (Stiglitz and Weiss, 1981) and hence banks might decide not to lend. The access to market by new companies might be difficult as well, as the market might believe that managers issue capital only when stocks are overvalued (Greenwald et al, 1984; Myers and Majluf, 1984) and, as a consequence, the offering might be undersubscribed.

VCs can be financial intermediaries (investment funds or investment banks) or non-financial companies (corporate VCs, government led initiatives or business angels - the latter are informal investors providing funds to new entrepreneurial ideas). The investment objective and the exit strategy might depend on the type of investors: financial intermediaries are usually more concerned with the return of investments, while corporate VCs (CVCs) might aim at technology transfer, that takes place during the investment, when CVCs have the opportunity to access the project funded and to follow its development (Basu et al., 2011). Should the CVCs find the product or service developed by the target interesting, it might then decide to acquire the firm or to buy the patent, for instance. Government-sponsored venture capitalists (GVCs), on their turn, might address funds to facilitate the development of a specific area or to promote entrepreneurship among the weakest groups of the population. The type of investor might also affect the level and quality of value added services provided by the VCs to the target, but empirical evidence on the effective contribution of the various type of investors is unclear (Luukkonen et al., 2013).

Exit strategies are commonly defined prior to investment and include IPO, trade sale, sale to the firm management or to other investors. The timing of exit and the effective disinvestment strategy are influenced by external factors, such as changes in the market conditions that can delay the exit or influence the return to the VCs. For instance, in case of IPOs, VCs might postpone the exit to avoid particularly adverse market conditions.

According to the European Venture Capital Association (EVCA, 2013) the most common exit strategy by counter value in Europe since 2007 to 2013 has been the trade sale (on average 40.3\% of the total amount at cost of disinvestments between 2007 and 2013), while contrary to expectations, IPOs involve only a limited percentage of the targets and of the counter value generated by the deals. Write offs involve $16 \%$ of the amount.

The economic cycle is one of the most relevant factors able to influence the availability of funds and the development of $\mathrm{VC}$, together with the regulatory and institutional framework of the investment country (Gompers et al, 1998; Jeng e Wells, 2000; Ayyagari et al, 2011; Bonini and Alkan, 2012), as well as the GDP, the presence of a developed secondary market for IPO and the characteristics of the job market (Gompers et al, 1998; Jeng and Wells, 2000). These features determine the level of attractiveness of a market for VCs and help in explaining the differences in the development of venture capital among the various countries (Bonini and Alkan, 2012; Ayyagari et al., 2011 for a study on emerging markets).

EVCA data (EVCA, 2013) on funding highlight a contraction of funds collected since 2007, year of the inception of the crisis. The negative trend continued until 2013 (despite an increase in 2011) 
when incremental funding stopped at 4.02 billion Euros, around half of the amount raised in 2007 (tab. 1).

Tab. 1: Funding for VCs

\begin{tabular}{|l|l|l|l|l|l|l|l|}
\hline Year & 2007 & 2008 & 2009 & 2010 & 2011 & 2012 & 2013 \\
\hline Funding & 8.15 & 6.21 & 3.63 & 3.21 & 5.17 & 3.86 & 4.02 \\
\hline $\begin{array}{l}\text { Figures in billion Euros. } \\
\text { Source: elaboration from EVCA, 2013. }\end{array}$ \\
\hline
\end{tabular}

In the last years, most of the funds of VC have been provided by governmental agencies, with a positive and growing contribution over time (tab. 2). Private investors follow, with around 16 percent in 2013. Corporate investors have been among the main contributors as well, especially between 2010 and 2013. Funds of funds have provided a relevant percentage of total funds in 2012 and 2013.

Tab. 2: Top 3 funds provider from 2007 to 2013

\begin{tabular}{|c|c|c|c|c|c|c|c|c|c|c|c|c|c|}
\hline \multicolumn{2}{|l|}{2007} & \multicolumn{2}{|c|}{2008} & \multicolumn{2}{|l|}{2009} & \multicolumn{2}{|l|}{2010} & \multicolumn{2}{|l|}{2011} & \multicolumn{2}{|c|}{2012} & \multicolumn{2}{|c|}{2013} \\
\hline $\begin{array}{l}\text { Private } \\
\text { individuals }\end{array}$ & 8.7 & $\begin{array}{l}\text { Private } \\
\text { individuals }\end{array}$ & 11.3 & $\begin{array}{l}\text { Government } \\
\text { agencies }\end{array}$ & 24.6 & $\begin{array}{l}\text { Government } \\
\text { agencies }\end{array}$ & 30.6 & $\begin{array}{l}\text { Government } \\
\text { agencies }\end{array}$ & 28.9 & $\begin{array}{l}\text { Government } \\
\text { agencies }\end{array}$ & 32.9 & $\begin{array}{l}\text { Government } \\
\text { agencies }\end{array}$ & 33.8 \\
\hline Banks & 8.3 & $\begin{array}{l}\text { Corporate } \\
\text { investors }\end{array}$ & 13.8 & \begin{tabular}{|l} 
Private \\
individuals
\end{tabular} & 11.6 & \begin{tabular}{|l} 
Private \\
individuals
\end{tabular} & 16.7 & $\begin{array}{l}\text { Corporate } \\
\text { investors }\end{array}$ & 12.3 & $\begin{array}{l}\text { Corporate } \\
\text { investors }\end{array}$ & 13.5 & \begin{tabular}{|l|} 
Private \\
individuals
\end{tabular} & 16.1 \\
\hline $\begin{array}{l}\text { Government } \\
\text { agencies }\end{array}$ & 7.9 & $\begin{array}{l}\text { Family } \\
\text { offices }\end{array}$ & 10.6 & Banks & 11.2 & $\begin{array}{l}\text { Corporate } \\
\text { investors }\end{array}$ & 13.4 & $\begin{array}{l}\text { Private } \\
\text { individuals }\end{array}$ & 12 & $\begin{array}{l}\text { Fund of } \\
\text { funds }\end{array}$ & 6.9 & $\begin{array}{l}\text { Fund of } \\
\text { funds }\end{array}$ & 8.7 \\
\hline
\end{tabular}

Figures represent the percentages of total incremental funds.

Source: elaboration from EVCA, 2013.

EVCA also shows that the targets operating in high tech industries represent on average $44.5 \%$ of investments and 35.9\% of target companies in VCs portfolios since 2007. More specifically, life sciences, computer and consumer electronics attract most of the funds available each year (EVCA, 2013).

\section{Data description and methodology}

To have a better insight on the portfolio choices of VCs operating in Europe, we examine information on investors and target portfolio firms obtained from ThomsonOne. We select a sample of VCs, requiring the VCs to have concluded at least one new deal since January 2003 and to disclose the sum invested, in order to analyse the evolution of investments both in terms of numbers and counter value. The final sample includes $43 \mathrm{VC}$ funds managed by 37 different managers.

The sample includes 38 financial intermediaries (32 investment funds, 3 investment banks and 3 other financial or banking institutions) that overall invested $95 \%$ of the sums received by the targets in the sample. There are also 2 corporate PE/venture funds, 1 business angel, 1 local business development programme and 1 evergreen investor.

Around $60 \%$ of the VCs in the sample are European and 35\% are US. Japan and Singapore are represented by one VC each.

The strong presence of US investors might be related to the strong tradition and historical development of VC in the United States. US investors might have built strong reputation and deep knowledge of their home market, which now enable them to operate also in distant countries. Additionally, more experienced VCs might receive more investment requests because of their stronger reputation, which is a key driver in the choice of the investment partner among targets. In fact, the literature finds that when the target firm has to choose among different investing proposals elaborated by different venture capitalists, the choice is taken on the basis of the reputation of the venture capitalist, rather than on the financial or contractual clauses (Hsu, 2004). 
Finally, US investors might be so numerous because they might take part to co-investment projects with European partners. Co-investments create the opportunity to join a deep knowledge of the market of the local venture capitalist and the reputation and competences of the more experienced non-local investors. Additionally, according to Cumming and Dai (2010), more experienced and higher reputation investors are less subject to local bias.

Most of the VCs declare to be mainly specialised in seed, early stage and later stage (27), while the others focus on balanced stage or other investment stages (16).

\section{Investment portfolio analysis}

The VCs in the sample invested in 1,172 targets $^{1}$ as at end March $2013^{2}$, with a total counter value of 4.82 billion Euros. The $38 \%$ of the investments was still in the investment portfolio at the same date.

On average every venture capitalist invested 112 million Euros. Only 7 VCs invested more than 200 million Euros, while the others invested lower amounts, with a minimum of 3 million (Figure I). The number of cumulated investments per venture capitalist ranges from 4 to 155 . The number of deals of each venture capitalist depends on various factors, such as the investment opportunities (e.g. the number of targets), the amount of funds raised by the VCs (the higher the funds available, the wider the investment opportunity set) and the investment strategy (some investors specify geographical or industry criteria, limiting the set of potential targets).

Figure II shows the average sum invested per target company, which is around 4 million Euros, ranging from 0.2 million to 13 million. In general, large VCs in the sample invest in a high number of targets, while the opposite holds for small investors, with few exceptions ${ }^{3}$.

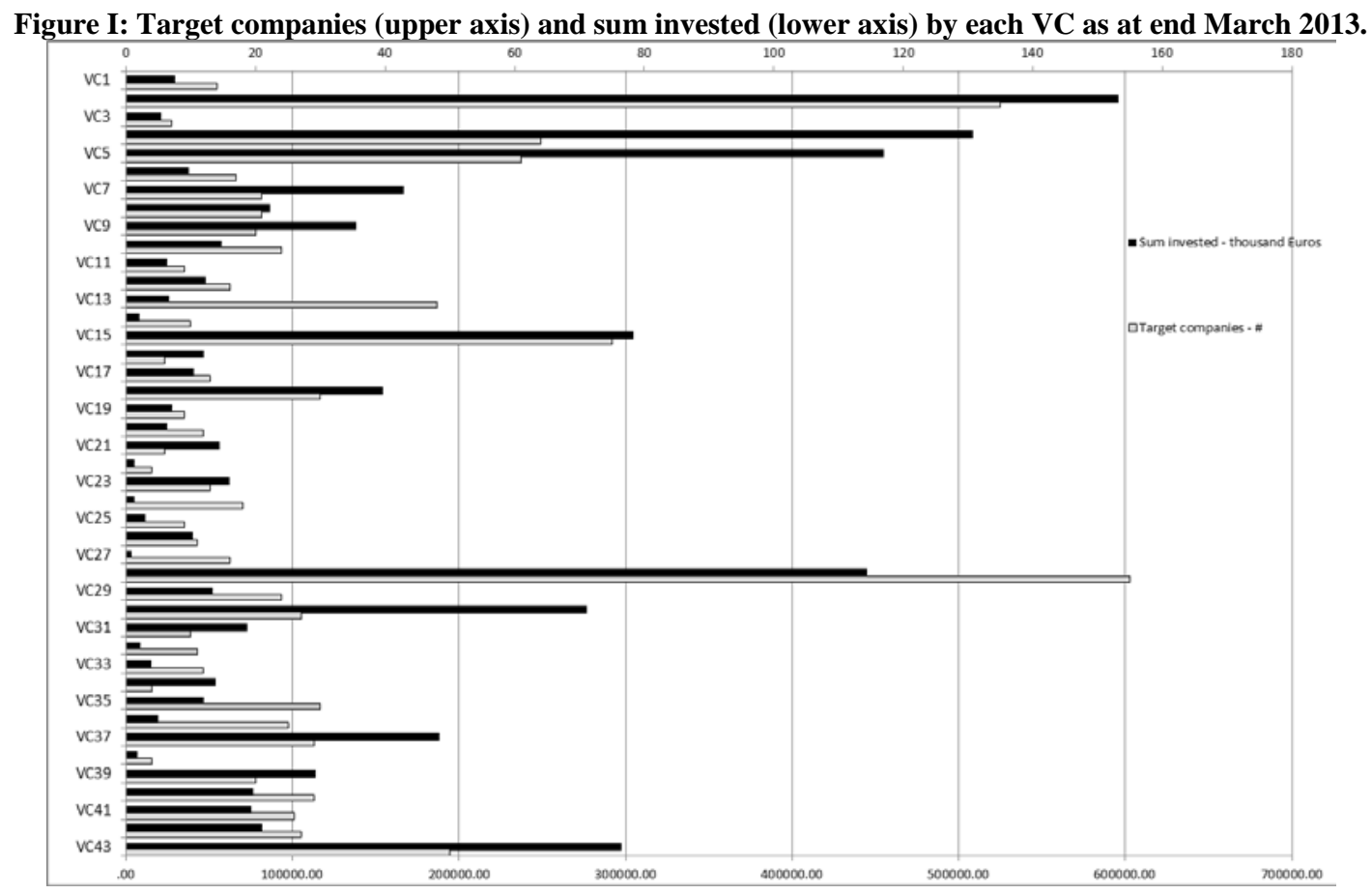

\footnotetext{
${ }^{1} 1,160$ are investments in targets and 12 in other funds.

2 The first investment done by the VCs in the sample was made in 1992, while the last in 2013.

${ }^{3}$ The correlation between sum invested and number of investments is $84 \%$.
} 
Figure II: average sum invested per target. Data in thousand Euros.

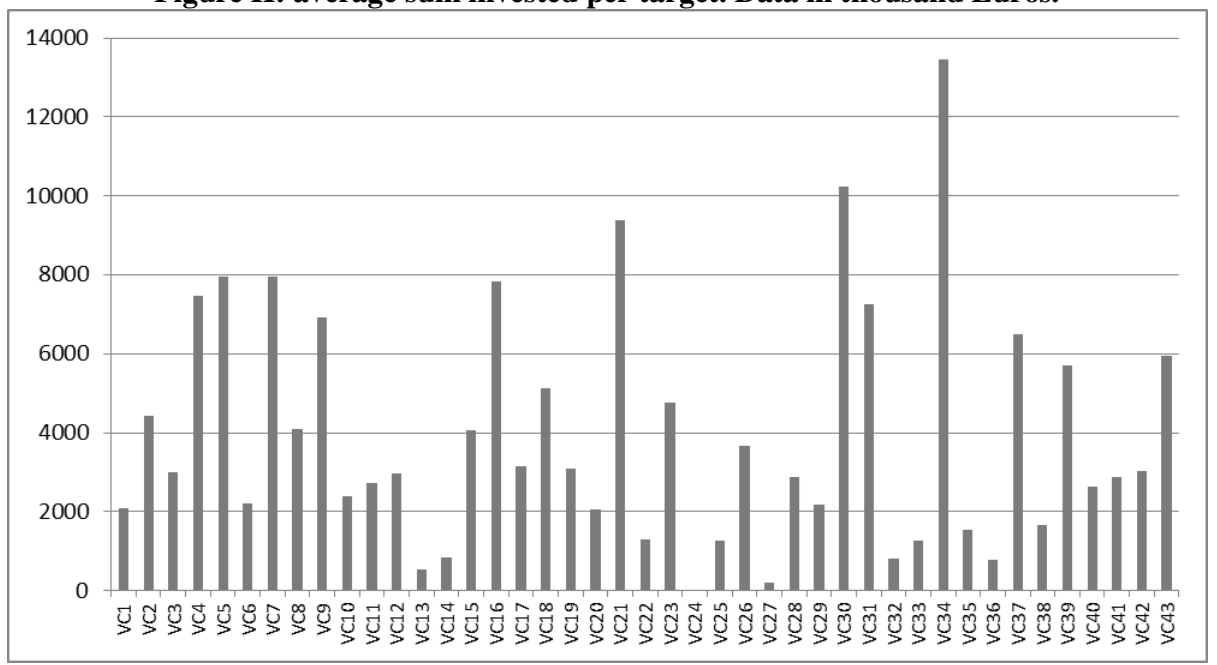

\subsection{Investment stage}

Around $85 \%$ of the sums invested are dedicated to the typical VC stages (seed, early stage, expansion and later stage). More in detail, the expansion stage absorbs $34.8 \%$ of the sums invested (1.7 billion Euros), followed by the early stage (1.2 billion). Also amounts for later stage are relevant, especially for investments in non-European targets (tab. 3). Some of the investments classified as later stage might relate to investments completed according to a staging strategy, i.e. the investor does not release all the funds at once, but splits the investment in more tranches which are made available according to a predetermined schedule.

Tab. 3: Sums invested by investment stage

\begin{tabular}{|c|c|c|c|c|c|c|}
\hline \multirow[b]{2}{*}{ Investment stage } & \multirow[b]{2}{*}{$\begin{array}{r}\text { Total } \\
(\mathrm{mln} €)\end{array}$} & \multicolumn{2}{|r|}{ Of which } & \multirow[b]{2}{*}{$\begin{array}{r}\text { Total } \\
(\%)\end{array}$} & \multicolumn{2}{|r|}{ Of which } \\
\hline & & Europe & $\begin{array}{r}\text { Rest of the } \\
\text { world }\end{array}$ & & Europe & $\begin{array}{r}\text { Rest of the } \\
\text { world }\end{array}$ \\
\hline Seed & 287.12 & 99.71 & 187.41 & $6.0 \%$ & $2.1 \%$ & $3.9 \%$ \\
\hline Early Stage & 1199.35 & 303.91 & 895.44 & $24.9 \%$ & $6.3 \%$ & $18.6 \%$ \\
\hline Expansion & 1674.13 & 503.84 & 1170.29 & $34.8 \%$ & $10.5 \%$ & $24.3 \%$ \\
\hline Later Stage & 935.11 & 246.67 & 688.44 & $19.4 \%$ & $5.1 \%$ & $14.3 \%$ \\
\hline Acq. for Expansion & 60.32 & 29.65 & 30.67 & $1.3 \%$ & $0.6 \%$ & $0.6 \%$ \\
\hline Acquisition & 139.02 & 90.77 & 48.25 & $2.9 \%$ & $1.9 \%$ & $1.0 \%$ \\
\hline Bridge Loan & 13.26 & 0.22 & 13.04 & $0.3 \%$ & $0.0 \%$ & $0.3 \%$ \\
\hline LBO & 148.74 & 120.43 & 28.31 & $3.1 \%$ & $2.5 \%$ & $0.6 \%$ \\
\hline MBI & 0.05 & 0.05 & 0.00 & $0.0 \%$ & $0.0 \%$ & $0.0 \%$ \\
\hline MBO & 176.89 & 176.89 & 0.00 & $3.7 \%$ & $3.7 \%$ & $0.0 \%$ \\
\hline Open market purchase & 3.99 & 1.20 & 2.79 & $0.1 \%$ & $0.0 \%$ & $0.1 \%$ \\
\hline Other & 0.09 & 0.00 & 0.09 & $0.0 \%$ & $0.0 \%$ & $0.0 \%$ \\
\hline PIPE & 62.09 & 5.42 & 56.68 & $1.3 \%$ & $0.1 \%$ & $1.2 \%$ \\
\hline Recap or Turnaround & 50.95 & 5.91 & 45.03 & $1.1 \%$ & $0.1 \%$ & $0.9 \%$ \\
\hline Secondary Buyout & 21.97 & 21.97 & 0.00 & $0.5 \%$ & $0.5 \%$ & $0.0 \%$ \\
\hline Secondary Purchase & 1.09 & 0.00 & 1.09 & $0.0 \%$ & $0.0 \%$ & $0.0 \%$ \\
\hline VC Partnership & 41.37 & 0.82 & 40.55 & $0.9 \%$ & $0.0 \%$ & $0.8 \%$ \\
\hline Total & 4815.52 & 1607.44 & 3208.08 & $100.0 \%$ & $33.4 \%$ & $66.6 \%$ \\
\hline Of which: $V C$ & 4095.70 & 1154.12 & 2941.58 & $85.1 \%$ & $24.0 \%$ & $61.1 \%$ \\
\hline
\end{tabular}




\subsection{Geographical diversification}

On average $42 \%$ of the investments involve foreign targets. The figure increases to $100 \%$ for some Swiss, Polish and Luxembourg investors (probably due to the limited size of the countries), while it is very low (4\%) for some US VCs, which might have a wider range of investment opportunities in their home market, and might decide to fund only few selected targets in non-domestic countries.

In the sample, $47 \%$ of targets are European (42\% of sums invested), while the remaining firms are mainly US (50\% of the total and $93 \%$ of non-European target companies). Investments in the US absorb the majority of sums invested (53\% of the whole sample portfolio and $96 \%$ of the sums invested in non-European targets).

Only 5 investors in the sample have injected capital in exclusively one country, while most of the VCs have invested in 2 to 5 foreign countries (Figure III). The first generally present a specific investment criteria that limits the area in which the VCs can invest. On the other hand, only one investment fund in the sample has a high degree of geographical diversification (19 countries). In fact, the risks of investing in foreign unknown markets can eliminate the potential benefits deriving from geographical diversification. Indeed, VCs should have a deep knowledge not only of the target company, but also of the regulatory and competitive framework in order to pursue a strong geographical diversification.

Geographical diversification can also be achieved through syndicated investments with foreign VCs. All the VCs in the sample, but one, have participated to syndicated investments, often with foreign co-investors.

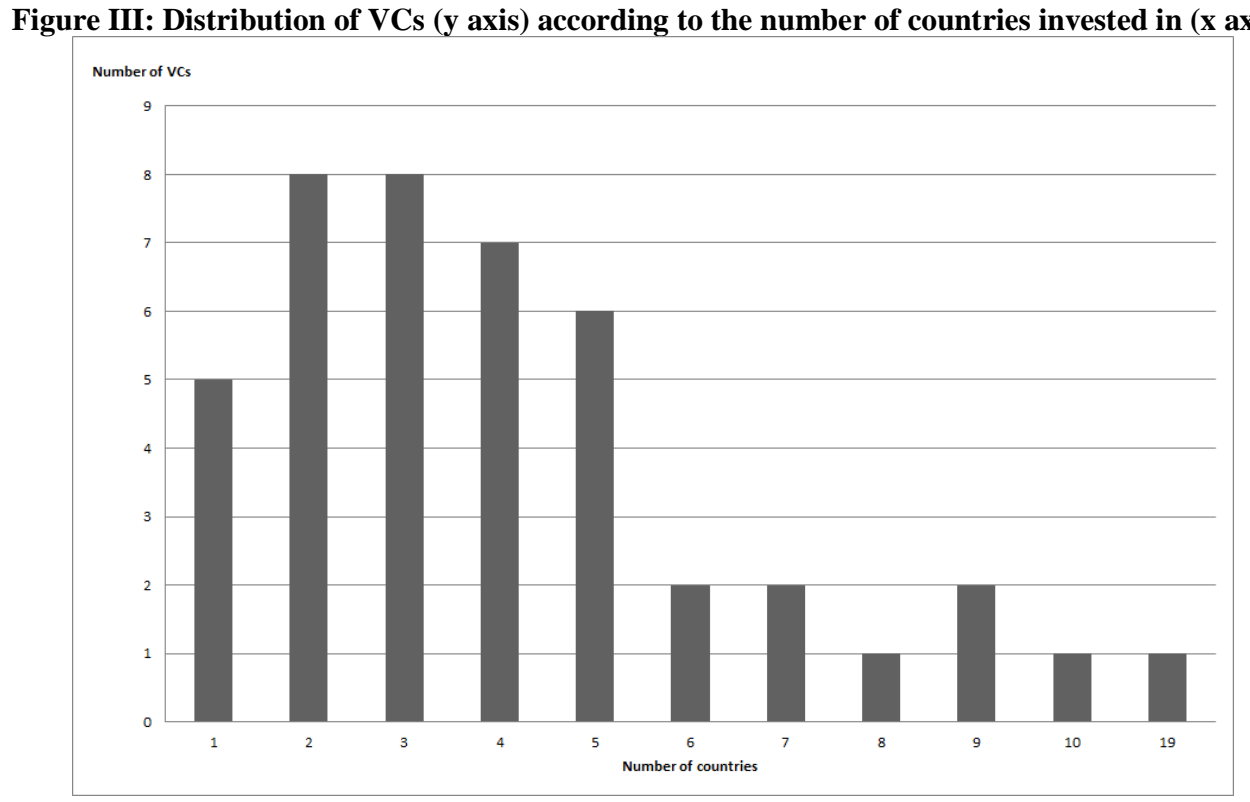

For all the VCs it is possible to individuate a main country and determine its importance on the basis of the number of target companies and sum invested ${ }^{4}$. On average, the $71 \%$ of the investments are concluded in the main country, which usually is also the country that receives the largest shares of funds (on average 69\% of total sums invested by each VC).

Despite European VCs are the most numerous in the sample, their overall portfolio weights only for the $33 \%$ of the sums invested, underlining an important contribution to funds invested in European

\footnotetext{
${ }^{4}$ Only in 6 cases the main country by number of investments and the main country by sum invested do not match. In case the number of investments in a given country is equal to the number of investments in another country, the main country is the one receiving a larger amount of funds.
} 
targets by VCs located in other areas (mainly the US). European VCs have invested around 80\% of the total amount of 1.6 billion euros in European targets, while non-European VCs have invested $22 \%$ of funds in European firms and the remaining 78\% outside Europe. Despite the strong international character of venture capital investments, data shows that investments in closer markets are still frequent and relevant, probably because of a better understanding and knowledge of the regulatory frameworks and market conditions of nearby countries. Additionally, European investors might have more difficulties in entering foreign markets (especially the US) for the presence of strong local competitors.

\subsection{Industry diversification}

A further source of diversification attains to the industry of the target. Evidence is in line with the data reported by EVCA (EVCA, 2013): the industries that receive more VC are life science (biotechnologies and medical) and ICT.

Indeed, in the sample, life science companies represent $37.4 \%$ of targets and absorb more than $47 \%$ of the sum invested (figure IV). Similar figures emerge for ICT companies which are $34.4 \%$ of the targets and received 28\% of the sums, for a total of 1.3 billion Euros. More traditional industries have received smaller amounts of funds. This is consistent with the preference of VCs for innovative projects, with a high rate of growth, which are more common in high technology industries.

In the sample, only one venture capitalist focuses on a single industry (Industry and Energy), while all the others pursue industry diversification. Most of the VCs that invested in biotechnology also invested in medical companies, probably exploiting specific knowledge and similar skills in evaluating the targets in these two industries. $37 \mathrm{VCs}$ invested at least in three different industries. One investment fund has invested in 16 different industries (the same venture capitalist that showed the highest degree of geographical diversification).

Figure IV: Investment distribution by industry: sum invested (million euros - right axis) and targets (left axis). 口Number of target companies

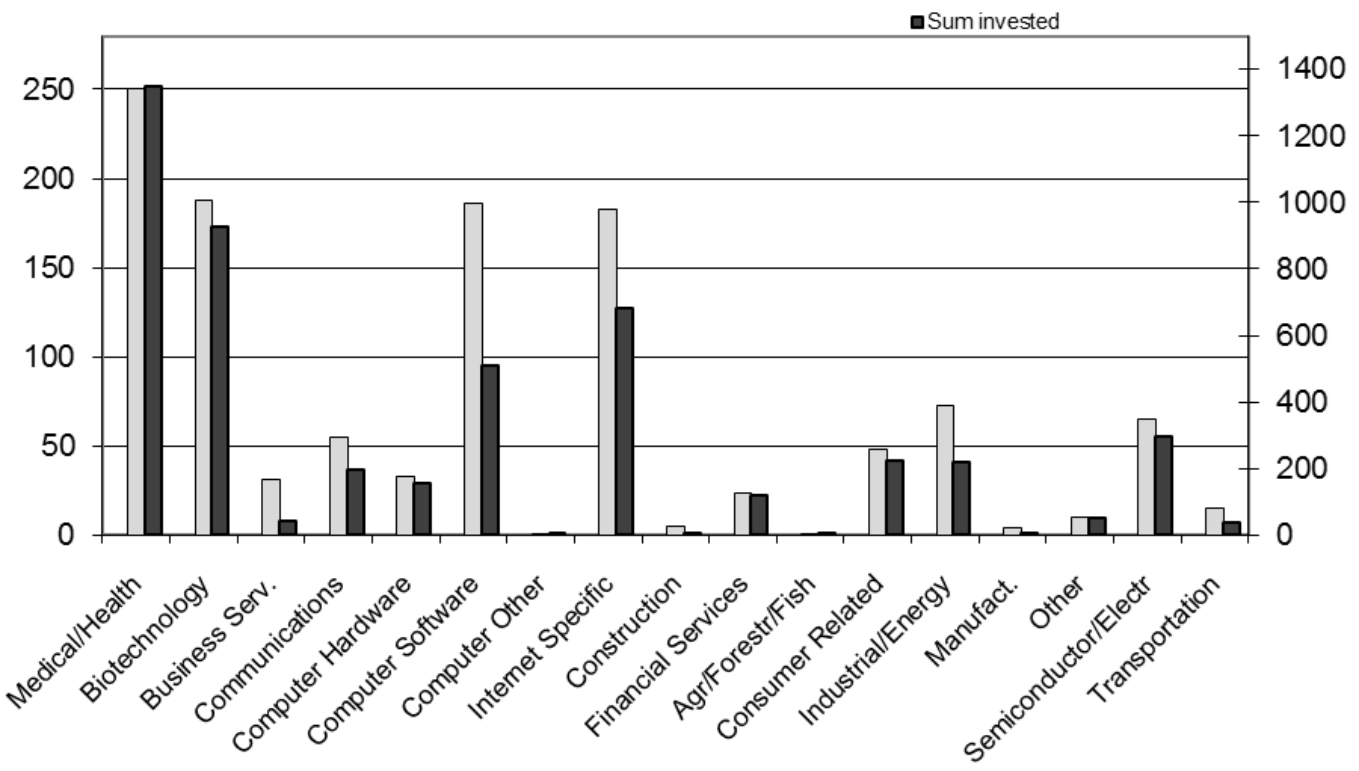

\subsection{Investment trend}

Another interesting aspect to evaluate is the evolution of investments in the latest years (from 2000 
to 2012), which can provide insight on the trend of investments during the latest crisis.

Overall the number of investments follows a positive trend during the full period. It is useful to provide more details on the pre and post-crisis statistics ${ }^{5}$. On average, $67 \%$ of active VCs have done at least one new investment each year, although the percentage decreases after the financial crisis. In fact, the figure is $71 \%$ for the period $2000-2006$, while it is $63 \%$ for the following period (20062012). The difference is positive and statistically significant, underlining a decrease in the ratio after 2007 (tab. 4).

Tab. 4: main descriptive statistics on the evolution of investments

\begin{tabular}{|l|l|l|l|}
\hline & $\begin{array}{c}\text { VCs that have } \\
\text { invested to total } \\
\text { active VCs }\end{array}$ & $\begin{array}{c}\text { Number of } \\
\text { yearly } \\
\text { investments }\end{array}$ & $\begin{array}{c}\text { Sum invested } \\
\text { (in million } \\
\text { Euros) }\end{array}$ \\
\hline Mean & 0.675 & 6.76 & 18.316 \\
\hline $\begin{array}{l}\text { Standard } \\
\text { deviation }\end{array}$ & 0.112 & 2.20 & 11.697 \\
\hline & & & \\
\hline Mean $2000-2006$ & 0.715 & 7.78 & 23.870 \\
\hline Mean $2007-2012$ & 0.630 & 5.57 & 11.836 \\
\hline difference & $0.085^{*}$ & $2.21^{* *}$ & $12.034^{* *}$ \\
\hline & & & \\
\hline T statistic & 1.42 & 2.03 & 2.25 \\
\hline $\begin{array}{l}\text { Unilateral test. } \mathrm{H}_{0}: \text { difference }=0 ; \mathrm{H}_{1}: \text { difference>0 } \\
* \text { statistical significance at } 10 \% ; * * \text { statistical significance at } 5 \%\end{array}$ \\
\hline
\end{tabular}

The crisis seems also to have impacted on the average number of investments per year. On the whole period this figure is 6.76 (computed as the ratio between the total investment in year $\mathrm{T}$ and the number of venture capitalist that have invested in year T). Before 2007 it is 7.78 million, while it decreases to 5.57 during the period 2007-2012. The difference between the two sub periods is 2.21 and it is positive and statistically significant (tab. 4).

Also when comparing the average sum invested ${ }^{6}$ for the period 2000-2006 to the period 2007-2012, we see a decrease from 23.87 to around 11.84 million. Again, when testing for the difference of means, we obtain a positive and significant difference (tab. 4).

It is possible to illustrate this phenomenon also graphically. Figure $\mathrm{V}$ shows the evolution of investments, both in terms of number of investments and in terms of sum invested starting from $2000^{7}$. The trend of investments is positive until 2004, when the figure reaches its maximum with more than 270 investments and around 700 million Euros invested. After that year, the figures drop, despite the slight increase between 2006 and 2007, and then diminishes again, until a very modest rise after 2010 (Figure VIII).

\footnotetext{
${ }^{5}$ Results of the following tests remain similar when taking 2008 as the first year of the crisis, instead of 2007.

${ }^{6}$ The average is computed as the ratio between total sum invested for a given year and number of venture capitalists that have invested in that year.

${ }^{7}$ The number of investment exceeds the number of firms if the VCs invest more than once in a target. The 1,172 targets received 1,900 rounds. The 7 investments (for a total of 146 million Euros) are excluded from the analysis.
} 
Figure V: Evolution of sum invested (th Euros, solid line, left axis) and number of investments (dotted line, right axis).

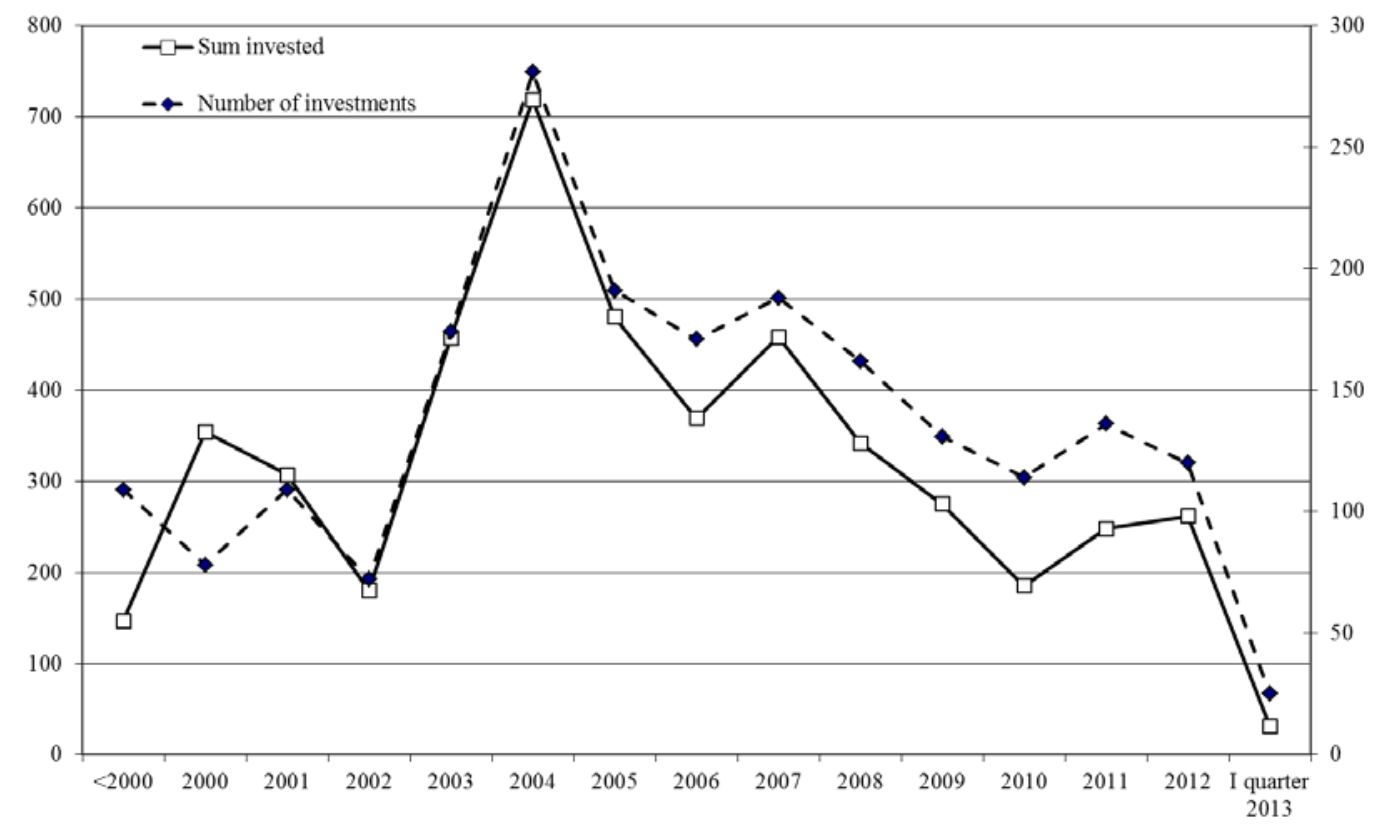

\section{Exit strategy and survivorship rate of targets}

The exit strategy is crucial in determining the performance of VC investment. Many factors contribute to the type of exit that can be pursued, such as the industry of the target company, the macroeconomic conditions and the characteristics of the VCs.

Of the total 1,172 investments, 12 are investments in other investment funds and are excluded from this analysis. Of the remaining 1,160 target companies, 437 were still in portfolio as at 31 March 2013. Almost all the target companies still in portfolio were active (94\%), while a small percentage was under LBO (4\%) (Tab. 5). Five companies went public (1\%) and three completed an acquisition (1\%).

With reference to exits, $43 \%$ of the companies have been acquired or merged to other firms. A relevant percentage of companies were active at the moment of disinvestment (32\%), when the company was transferred to another investor (such as private equity fund), while the defunct or bankrupt companies where $10 \%$ of the exits; $4 \%$ was under LBO. The others have concluded an IPO (12\%).

Tab. 5: Status of target companies

\begin{tabular}{|l|l|c|c|c|}
\hline & & $\begin{array}{c}\text { Number of } \\
\text { companies }\end{array}$ & as \% of Total & as \% on sub-total \\
\hline Exit & 723 & $62 \%$ & \\
\hline Of which & Acquisition & 286 & & $40 \%$ \\
\hline & Pending acquisition & 5 & & $1 \%$ \\
\hline & Active (transferred to other investors) & 231 & & $32 \%$ \\
\hline & Merger & 13 & & $2 \%$ \\
\hline & In registration & 1 & & $0 \%$ \\
\hline & LBO & 32 & & $4 \%$ \\
\hline & Went public & 84 & & $12 \%$ \\
\hline & Bankrupt & 6 & & $9 \%$ \\
\hline & Defunct & 65 & & \\
\hline & & & & 9 \\
\hline
\end{tabular}




\begin{tabular}{|l|l|c|c|c|}
\hline \multicolumn{2}{|l|}{ Still in portfolio } & 437 & $38 \%$ & \\
\hline Of which & Acquisition & 3 & & $1 \%$ \\
\hline & Active & 409 & & $94 \%$ \\
\hline & LBO & 19 & & $4 \%$ \\
\hline & Went public & 5 & & $1 \%$ \\
\hline & Defunct & 1 & & $0 \%$ \\
\hline \multicolumn{2}{l|}{ Total } & 1,160 & $100 \%$ & \\
\hline
\end{tabular}

If we assume that the worst scenario for a VC portfolio is represented by bankruptcy and failure of the target companies, we can proxy the success of a VCs portfolio with the rate of survivorship of the target companies, defined as $S=1-\Omega$, where $\Omega$ is the percentage of companies with status 'bankrupt' or 'defunct'. In the sample considered, the number of bankrupt companies is 6 , while the defunct are 66. Overall, the $\Omega$ of the sample is hence $6.2 \%$ (72 companies out of 1,160 ) and therefore the value of $\mathrm{S}$ is $93.8 \%$. The determinants of the survivorship rate might relate to several target and investors characteristics, influencing the level of diversification of the portfolio and investment strategies. We expect that VCs focusing on one industry are more subject to shocks in the specific industry, such that, when a negative event causes the failure of a business project (or company), it might cause the failure of other similar or related projects or companies. One example might be the introduction of a new regulation after the investment has already taken place: for instance, for life science targets, a new rule that hinders the use of specific methodologies, such as clonation, or specific procedures which are recognised to be dangerous or unethical. This might have a negative effect on the expected profitability of targets, which are already funded, that make use of these methodologies or procedures. The same holds for geographical concentration and the effects of country specific shocks on the portfolio. Nevertheless, a certain degree of geographical and industrial specialization might help the VCs in raising knowledge and competencies of specific industries or markets, and hence improving their screening activity when selecting their investment targets.

Additionally, VCs investing only in companies in one stage might not diversity their investment maturity. For instance, the level of uncertainty is higher during the seed stage and hence the level of risk is higher. Staging is a way to dilute investments over time and increase monitoring. These activities, together with other value added services, help in boosting the target performance, reducing the probability of bankrupt, and hence increasing VCs return at exit. Reputation and experience play a major role in the screening phase and hence we expect targets financed by more experienced VCs to have a higher rate of success. Besides, risk of a single investment should be lower for a given venture capitalist if the latter participate to a syndicated investment, where also other VCs and investors bear the risk of the business project. Finally, because of their specific competencies, VCs that are financial intermediaries should be able to provide higher quality services, with beneficial effects on the target performance, which should translate into lower default rate.

The expectations above described are summarised by the following equation.

$\mathrm{S}=\alpha+\beta_{1} \mathrm{~N} \_$Ind $+\beta_{2} \mathrm{~N} \_$Country $+\beta_{3} \mathrm{~N} \_$Stage $+\beta_{4}$ Year $+\beta_{5} \mathrm{~N} \_$inv $+\beta_{6} \mathrm{SI}$ inv $+\beta_{7}$ Synd_foreign + $\beta_{8}$ EU $+\beta_{9}$ Fund $+\beta_{10}$ Bank $+v$

Where

- $\quad$ N_Ind: number of industry where the VC invested

- N_Country: number of countries where the VC invested

- $\quad$ N_Stage: number of stages where the VC invested

- Year: vintage year of the VC 
- $\quad \mathrm{N} \_$inv: percentage of investments in the main country

- SI_inv: percentage of sum invested in the main country

- synd_foreign: percentage of foreign co-investors

- EU: dummy equal to 1 for European VCs, 0 otherwise

- Fund: dummy equal to 1 for investment funds, 0 otherwise

- Bank: dummy equal to 1 for investment banks, 0 otherwise

- v: error term

Table 6 shows the regression results. Starting from the complete model, five different specification are tested. Geographical diversification appears to have a positive and significant impact on survivorship, although the relevance of the main country plays a major role as well. This might convey the idea that the better the knowledge of the main country, the higher the success; however, everything else equal, VCs that are able to diversify geographically have a more successful portfolio than others. Industry diversification shows a negative and significant sign. VCs that are focused on a limited number of industries are able to better evaluate investment opportunities and to increase the survivorship of the VC backed firms. Year shows a positive sign, suggesting that more experienced VCs obtain lower survivorship rate. While this might be counterintuitive, further research might clarify these results. Some possible explanations include the fact that younger VCs might be more aggressive and able, therefore, to attract the best fund managers with better screening and monitoring skills. Moreover, they might apply stricter investment criteria to build a good reputation during their first years of activity. Finally, the vintage year of the VC does not coincide with the vintage year of the management firm. With reference to the dummy isolating European VCs, results show that their portfolios have a higher level of survivorship if compared to non-European investors.

The remaining control variables do not seem to have a significant impact on survivorship. In particular, the dummies for investment funds and investment banks are not statistically significant, suggesting that financial intermediaries' portfolios have a level of success comparable to other VCs.

Tab. 6: Regression results

\begin{tabular}{|c|c|c|c|c|c|}
\hline & 1 & 2 & 3 & 4 & 5 \\
\hline n_ind & $-0.008 *$ & $-0.008 *$ & $-0.008 *$ & $-0.009 * *$ & $-0.009 * *$ \\
\hline n_country & 0.009 & $0.008^{*}$ & 0.008* & $0.008 *$ & $0.008 *$ \\
\hline n_stage & -0.001 & & & & \\
\hline year & $0.005^{* * *}$ & $0.005 * * *$ & $0.005 * * *$ & $0.005 * * *$ & $0.005 * * *$ \\
\hline n_inv & $0.199 * *$ & $0.200 * *$ & $0.183 * *$ & $0.142 *$ & $0.087 *$ \\
\hline si_inv & -0.078 & -0.081 & -0.077 & -0.063 & \\
\hline synd_foreign & 0.031 & 0.033 & 0.028 & & \\
\hline eu & $0.040 * *$ & $0.042 * *$ & $0.042 * *$ & $0.041^{* *}$ & $0.036 * *$ \\
\hline fund & -0.018 & -0.018 & -0.023 & -0.030 & -0.028 \\
\hline bank & 0.017 & 0.017 & & & \\
\hline constant & $-8.565 * *$ & $-8.664 * *$ & $-8.657 * *$ & $-8.936 * * *$ & $-9.162 * * *$ \\
\hline $\mathrm{R}^{2}$ & 0.48 & 0.48 & 0.48 & 0.47 & 0.45 \\
\hline Adj. $\mathrm{R}^{2}$ & 0.32 & 0.34 & 0.36 & 0.36 & 0.36 \\
\hline
\end{tabular}

\section{Conclusions}

Understanding the determinants of VC success appears of outmost importance especially for the development of entrepreneurship and the support of business during crisis periods, when new 
ventures might find difficulties in accessing the traditional funding channels. The literature shows how VC can be the most suitable form of financing for new businesses, as it can overcome the asymmetries of information that characterise companies at their first stage of life cycle and perform screening and monitoring services that contribute to the success of the target.

This paper has investigated the behaviour of VCs that invested in Europe, to evaluate the composition of their portfolios and to highlight which factors might contribute to level of survivorship of their portfolio firms. Evidence shows that VC investments follow a cyclical behaviour and the number and counter value of investments has decreased after the latest financial crisis. Furthermore, the survivorship rate of investment portfolios appears related to country and industry diversification and the degree of knowledge of the market.

Further research is needed to shed light to a number of aspects concerning, among others, venture capital investment strategies, the impact of the various characteristics of VCs (not limited to type and age) on the level of survivorship of portfolio firms, as well as target and VC performance levels during boom and crisis periods.

\section{References}

Ayyagari M, Demirgüç-Kunt A, Maksimovic V, 2011. Firm innovation in emerging markets: the role of finance, governance and competition. Journal of Financial and Quantitative Analysis, 46, 1545-1580.

Barry CB, Muscarella CJ, Peavy III JW, Vetsuypens MR, 1990. The role of venture capital in the creation of public companies. Journal of Financial Economics, 27, 447-471.

Basu S, Phelps C, Kotha S, 2011. Towards understanding who makes corporate venture capital investments and why. Journal of Business Venturing, 26, 153-171.

Bonini F, Alkan S, 2012. The political and legal determinants of venture capital investments around the world. Small Business Economics, 39, 997-1016.

Brav A, Gompers PA, 1997. Myth or Reality? The long-run Underperformance of Initial Public Offerings: Evidence from Venture and Non-venture Capital-Backed Companies. The Journal of Finance, 52, 1791-1821.

Brau J, Brown RA, Osteryoung JS, 2003. Do Venture capitalists Add Value to Small Manufacturing Firms? An Empirical Analysis of Venture and Nonventure Capital-Backed Initial Public Offerings. Journal of Small Business Management, 42, 78-92.

Croce A, Martì J, Murtinu S, 2013. The impact of venture capital on the productivity growth of European entrepreneurial firms: 'screening' or 'value-added' effect? Journal of Business Venturing, 28, July 2013, 489-510.

Cumming D, Nai D, 2010. Local bias in venture capital investments. Journal of Empirical Finance, 13, 362-380.

Dal-Pont Legrand M, Pommet S, 2010. Venture capital syndication and the financing of innovation: financial versus expertise motives. Economic Letters 106, 75-77. 
EVCA, 2013. Yearbook 2013 - Activity data on Fundraising, Investments and Divestments by Private Equity and Venture Capital Firms in Europe, www.evca.eu.

Greenwald B, Stiglitz J, Weiss Al, 1984. Informational imperfections in the capital markets and macro-economic fluctuations. American Economic Review, 74, 194-199.

Gompers P, 1995. Optimal investment, monitoring, and the staging of venture capital. Journal of Finance, 50, 1461-1490.

Gompers P, 1996. Grandstanding in the venture capital industry. Journal of Financial Economics, 42, 133-156.

Gompers P, Lerner J, Blair M, Hellmann T, 1998. What Drives Venture Capital Fundraising? Brookings Papers on Economic Activity. Microeconomics, 1998, 149-204.

Hsu D, 2004. What do entrepreneurs pay for venture capital affiliation? Journal of Finance 59, 1805-1844.

Jain B, Kini O, 2000. Does the presence of Venture Capitalists improve the survival profile of IPO firms? The Journal of Business Finance and Accounting, 27, 1139-1183.

Jeng LA, Wells PC, 2000. The determinants of venture capital funding: evidence across countries. Journal of Corporate Finance, 6, 241-289.

Kaplan S, Stromberg P, 2001. Venture Capitalists as Principals: contracting, screening and monitoring. American Economic Reviews papers and proceedings.

Luukkonen T, Deschryvere M, Bertoni F, 2013. The value added by government venture capital funds compared with independent venture capital funds. Technovation, 33, 154-162.

Metrick A., Yasuda A., 2011. Venture capital and other private equity: a survey. European Financial Management, 17, 619-654.

Myers SC, Majluf NS, 1984. Corporate financing and investment decisions when firms have information that investors do not have. NBER Working Paper 1396.

Stiglitz JE, Weiss A, 1981. Credit rationing in markets with imperfect information. The American Economic Review, 71, 393-410. 


\section{Appendix}

Tab. A1: Main country in which venture capitalists invest.

\begin{tabular}{|c|c|c|c|c|c|c|c|c|c|}
\hline$n$ & Venture capitalist & $\begin{array}{l}\text { Main country by } \\
\text { number of } \\
\text { investments }\end{array}$ & $N$ investments & $\begin{array}{lr}\text { Main } & \text { country } \\
\text { by } & \text { sum } \\
\text { invested } & \end{array}$ & $\begin{array}{l}\text { Sum } \\
\text { invested } \\
\text { (th Euros) }\end{array}$ & $\begin{array}{l}\text { Total } \\
\text { investments }\end{array}$ & $\begin{array}{l}\text { Total sum } \\
\text { invested (th } \\
\text { Euros) }\end{array}$ & $\begin{array}{l}\text { Main country } \\
\text { investments as } \\
\% \text { of Total } \\
\text { investments }\end{array}$ & $\begin{array}{l}\text { Main country } \\
\text { SI as \% of } \\
\text { Total SI }\end{array}$ \\
\hline 1 & VC1 & France & 8 & France & 15026.9 & 14 & 29239.4 & $57 \%$ & $51 \%$ \\
\hline 2 & VC2 & UK & 49 & Germany & 181033.1 & 136 & 595699.6 & $36 \%$ & $30 \%$ \\
\hline 3 & VC3 & France & 6 & France & 17353.0 & 7 & 21051.8 & $86 \%$ & $82 \%$ \\
\hline 4 & VC4 & USA & 40 & USA & 276829.7 & 61 & 455328.6 & $66 \%$ & $61 \%$ \\
\hline 5 & VC5 & USA & 40 & USA & 310175.0 & 64 & 508336.1 & $63 \%$ & $61 \%$ \\
\hline 6 & VC6 & Germany & 8 & Germany & 20909.1 & 17 & 37721.5 & $47 \%$ & $55 \%$ \\
\hline 7 & VC7 & USA & 7 & UK & 49192.5 & 21 & 166714.9 & $33 \%$ & $30 \%$ \\
\hline 8 & VC8 & Switzerland & 16 & Switzerland & 52032.1 & 21 & 86252.1 & $76 \%$ & $60 \%$ \\
\hline 9 & VC9 & USA & 19 & USA & 134557.5 & 20 & 138250.2 & $95 \%$ & $97 \%$ \\
\hline 10 & VC10 & USA & 20 & USA & 47554.2 & 24 & 57553.9 & $83 \%$ & $83 \%$ \\
\hline 11 & VC11 & Germany & 4 & UK & 7305.9 & 9 & 24627.5 & $44 \%$ & $30 \%$ \\
\hline 12 & VC12 & Portugal & 8 & Portugal & 26059.4 & 16 & 47632.3 & $50 \%$ & $55 \%$ \\
\hline 13 & VC13 & UK & 48 & UK & 26128.4 & 48 & 26128.4 & $100 \%$ & $100 \%$ \\
\hline 14 & VC14 & Austria & 5 & Austria & 2777.7 & 10 & 8280.0 & $50 \%$ & $34 \%$ \\
\hline 15 & VC15 & USA & 71 & USA & 266963.2 & 75 & 304714.5 & $95 \%$ & $88 \%$ \\
\hline 16 & VC16 & USA & 3 & USA & 36349.7 & 6 & 46965.8 & $50 \%$ & $77 \%$ \\
\hline 17 & VC17 & USA & 10 & USA & 34079.2 & 13 & 40860.5 & $77 \%$ & $83 \%$ \\
\hline 18 & VC18 & USA & 28 & USA & 144245.6 & 30 & 154091.7 & $93 \%$ & $94 \%$ \\
\hline 19 & VC19 & Norway & 7 & Norway & 25910.7 & 9 & 27877.7 & $78 \%$ & $93 \%$ \\
\hline 20 & VC20 & Germany & 6 & Germany & 18259.1 & 12 & 24808.0 & $50 \%$ & $74 \%$ \\
\hline 21 & VC21 & Norway & 2 & Norway & 18802.6 & 6 & 56306.5 & $33 \%$ & $33 \%$ \\
\hline 22 & VC22 & USA & 2 & Finland & 2499.8 & 4 & 5232.4 & $50 \%$ & $48 \%$ \\
\hline 23 & VC23 & USA & 8 & USA & 49956.0 & 13 & 61969.1 & $62 \%$ & $81 \%$ \\
\hline 24 & VC24 & UK & 18 & UK & 5328.0 & 18 & 5328.0 & $100 \%$ & $100 \%$ \\
\hline 25 & VC25 & Lithuania & 3 & Russia & 4592.0 & 9 & 11431.0 & $33 \%$ & $40 \%$ \\
\hline 26 & VC26 & USA & 7 & USA & 20563.6 & 11 & 40324.0 & $64 \%$ & $51 \%$ \\
\hline 27 & VC27 & Finland & 16 & Finland & 3088.8 & 16 & 3088.8 & $100 \%$ & $100 \%$ \\
\hline 28 & VC28 & USA & 103 & USA & 335908.4 & 157 & 445185.5 & $66 \%$ & $75 \%$ \\
\hline 29 & VC29 & USA & 23 & USA & 48845.5 & 24 & 51985.9 & $96 \%$ & $94 \%$ \\
\hline 30 & VC30 & USA & 26 & USA & 270583.0 & 27 & 276610.0 & $96 \%$ & $98 \%$ \\
\hline 31 & VC31 & USA & 5 & Germany & 34250.7 & 10 & 72662.2 & $50 \%$ & $47 \%$ \\
\hline 32 & VC32 & UK & 11 & UK & 8750.5 & 11 & 8750.5 & $100 \%$ & $100 \%$ \\
\hline 33 & VC33 & USA & 9 & USA & 7868.2 & 12 & 15268.9 & $75 \%$ & $52 \%$ \\
\hline 34 & VC34 & Russia & 4 & Russia & 53852.0 & 4 & 53852.0 & $100 \%$ & $100 \%$ \\
\hline 35 & VC35 & USA & 16 & USA & 26681.8 & 30 & 46446.1 & $53 \%$ & $57 \%$ \\
\hline 36 & VC36 & UK & 20 & UK & 16107.8 & 25 & 19465.2 & $80 \%$ & $83 \%$ \\
\hline 37 & VC37 & USA & 25 & USA & 165661.2 & 29 & 187900.1 & $86 \%$ & $88 \%$ \\
\hline 38 & VC38 & Estonia & 2 & Estonia & 4000.2 & 4 & 6600.8 & $50 \%$ & $61 \%$ \\
\hline 39 & VC39 & USA & 8 & USA & 56778.2 & 20 & 114102.6 & $40 \%$ & $50 \%$ \\
\hline 40 & VC40 & Switzerland & 24 & Switzerland & 62147.7 & 29 & 76210.8 & $83 \%$ & $82 \%$ \\
\hline 41 & VC41 & USA & 25 & USA & 45160.9 & 26 & 75169.3 & $96 \%$ & $60 \%$ \\
\hline 42 & VC42 & USA & 26 & USA & 51697.1 & 27 & 81705.6 & $96 \%$ & $63 \%$ \\
\hline 43 & VC43 & USA & 48 & USA & 255507.0 & 50 & 297791.7 & $96 \%$ & $86 \%$ \\
\hline
\end{tabular}

